\title{
Nature, economics, property and commons. Subversive notes inspired by Elinor Ostrom
}

Vincenzo M. Lauriola

INPA (National Research Institute of the Amazon), Av. André Araújo 2936, 69067-375 Manaus, Amazonas, Brazil

\begin{abstract}
Nature-economy relations also are the result of economics' concepts, ideas and paradigms. Heterodox economic views and paradigms are urgently needed to foster shifts towards the planet's future sustainability paths. Elinor Ostrom, 2009 Nobel economics laureate, stands as one of the authors whose long neglected views are most inspiring in subverting mainstream paradigms on property regimes and natural resource management. Challenging the tragedy of the commons orthodoxy, she shows humans are able to escape the prisoner's dilemma, as well as the public vs private property, and state vs market modern dichotomy in natural resources' management models, by recognizing common property as a third option, and re-inventing the commons as indeed diverse and resilient institutions to foster more sustainable economy-nature relations. Brazil's indigenous territories are cited as a living example of commons' sustainability, although increasingly threatened by economic growth.
\end{abstract}

\section{Natural Resources and economics: some ambiguities}

A resource is any "material or immaterial thing apt to meet human needs", hence having use value. The resource notion implies forms of appropriation and use, linked to "natural things", to meet human needs. Most natural resources are selected, appropriated and used according to socio-culturally defined forms. Socio-cultural organization, including economy, knowledge, rights and technology, defines the (quantitative and qualitative) features of what is useful, having use value.

Some natural resources also have economic value: those being useful and scarce. Scarcity is a necessary condition for "exchange value" to exist: abundant resources have no price, as none is willing to pay to access abundant and accessible resources. Use value and exchange value diverge due to scarcity. An example is air: it has very high use value but, being abundantly accessible, none is willing to pay to breathe, and its economic value is nil (or almost: clean areas gain value due to air pollution).

Table 1: Nature, use value and exchange value.

\begin{tabular}{|c|c|c|c|c|}
\hline Category & Relation & Category & Relation & Category \\
\hline NT & $\supset$ & NR & $\supset$ & ENR \\
\hline Natural Things & $\begin{array}{c}\text { Strict } \\
\text { inclusion }\end{array}$ & Natural Resources & $\begin{array}{c}\text { Strict } \\
\text { inclusion }\end{array}$ & $\begin{array}{c}\text { Economic Natural } \\
\text { Resources }\end{array}$ \\
\hline NATURE & $\Rightarrow$ utility $\Rightarrow$ & USE VALUE & $\Rightarrow$ scarcity $\Rightarrow$ & EXCHANGE VALUE \\
\hline
\end{tabular}

What determines scarcity? How and why does a NR become scarce, and turn an ENR? Economic theory implicitly assumes that to happen as a NR "naturally" turns scarce. Hence, the emergence of economic value is held to indicate an unbalance between the useful resource's demand and its "natural" supply.

Can we hold such a reading exhaustive and/or satisfactory? More than a "natural" consequence of historical demographical processes, could the scarcity turning NRs into ENRs not be the consequence of other socially determined processes? How do socio-cultural NRs' appropriation and use forms interfere? Could those forms not contribute to produce the scarcity needed for economic value to emerge? Could NRs' exclusive appropriation forms not partially be "artificial", not the result of resources'

${ }^{1}$ Contact: enzo@inpa.gov.br ; enzolauriola@gmail.com. 
scarce natural supply, but straightly functional to breed exchange value, making users pay for resources no longer freely accessible?

Among the first economists, David Ricardo, in his differential rent theory stated that a good's or productive input's quality value is determined by its relative scarcity. Referring to land, Ricardo observed that: a) when demand exceeds the most fertile lands' productive capacity, and less fertile lands are cultivated, as productive "quality", fertility becomes a relatively scarce input, giving rise to a "differential rent", direct consequence of the "natural" quality differential; b) land differential rent not only emerges because its natural productivity features are given and physically linked to it, but also because land is appropriated and immobile. Referring to other natural productive inputs, he says: "If water, air, steam compressibility and atmosphere pressure were of variable quality, if they were appropriable and each of their qualities only existed in reduced quantities, as land, they would provide a rent function of the use of their successive qualities" [8].

At dawn of political economic thinking it was clear that natural resources' scarcity can be socially produced, as far as science, technology and social organization determine natural resources' appropriation forms, by influencing social perception of their relative scarcity. It is a point to bear in mind, upon which ethical questioning cannot be avoided, when we deal with the earth's limits' issue, by asking ourselves if and to what extent those limits do not (more or less unduly) legitimize nature's privatization or commodification.

\section{Natural resources and property regimes}

In building an analytical framework of natural resources' institutional management forms' diversity (Institutional Analysis and Development framework - IAD) Elinor Ostrom, Nobel prize for economics in 2009 [3], classifies resources following two physical-economic main features:

a) exclusion: extent to which it is physically, legally and/or economically possible to exclude users from resource access;

b) rivalry (or subtractability): extent to which, if used by an individual, a resource is no longer available for use by another individual.

An analytical matrix can be built to observe the crossing between goods' features and the main property regimes adopted. In general, easily excludable and highly rival resources are held in private property, whereas in cases of difficult exclusion and low rivalry we have public goods.

Table 2. Resources' physical-legal-economic features and property regimes

\begin{tabular}{|c|c|c|}
\hline Exclusion/Rivalry & High rivalry & Low rivalry \\
\hline Easy exclusion & Private goods & Toll goods \\
\hline Difficult exclusion & Common Pool Resources (CPR's) & Public goods \\
\hline
\end{tabular}

Source: [6].

Besides these cases, well studied by economics, there are two more categories: toll goods, of easy exclusion and low rivalry, and common pool resources (CPRs), of difficult exclusion and high rivalry. Toll goods show well how scarcity's social production works with the goal of giving rise to a rent. Let us take a leisure use beach: exclusion is simple, by a simple enclosure. Beaches' exclusive appropriation produces their scarcity, allowing their "owner" to charge toll on excluded individuals, thus giving rise to a rent. All can be relatively independent from "natural" availability: even if these are abundant in relation to social demand for leisure beaches (low use rivalry), exclusive use enclosures' extension determines the feasible "scarcity rent" level.

For natural resources, the most interesting case is Common Pool Resources (CPR's), goods of difficult exclusion and highly rival, as it reflects most environmental problems, linked to "free" resources the use of which is rival and conflict-rising.

Mainstream economic analysis reduces environmental problems to the absence of property rights on CPR's. That is why CPRs' costs stay out of optimizing economic calculations, outlining the so-called "externalities". The solution proposed directly follows from the adopted analytical framework: defining property rights to "internalize externalities". Once "correctly" re-defined goods' and services' prices, also incorporating free natural resources' and environmental impacts' relative scarcity, economic actors would take account of them, and externalities would vanish. Against that "orthodox" approach, followed by the environmental economics school-of-thought, stand other critical approaches, hence "heterodox", many of which converge in the ecological economics school. Their key divergence can be summarized as follows: starting from the common observation of a gap between the economy and the environment, environmental economics tries to bridge it by extending market regulation on the 
environment, due to the market's ability to produce equilibria; ecological economics instead tries to bring the economic system's scale and working to be more compatible with the ecosystem's limits and own laws.

\section{Reading and classifying property}

What is property? We can define it an institution through which humans regulate among themselves rights to use things. Abstracting from the wide historical-cultural diversity featured in human institutions with that goal, it is possible to analyze some key features starting from the property concept in roman law.

In the "roman" property concept a full owner has 3 rights upon a thing:

1) usus, right to directly use the thing to meet his/her needs;

2) fructus, right to use its fruits;

3) abusus, right to freely dispose of his/her rights on the thing, by transferring their entitlement, but also by reducing them down to nil, by destroying the thing.

The combination of the first two rights can be summarized in terms of "access", while the third describes access rights' transferability.

Modern State law systems (especially roman law based systems, less common law based ones) basically recognize two property regimes: private property, whose subject is an individual, physical or juridical person, and public property, whose subject is the State, or public law juridical person. Property regimes reflect the dichotomy of subjects recognized by the modern State, space where the individual relates directly with the only collective entity formally recognized: the State. Normal forms of property are hence private individual and public state property. Other forms or regimes, such as feudal rights and properties, pre-existing to the modern State, are seen as exceptions, anomalies to be removed for modernity's progress.

To escape that dichotomy one can use a wider analytical grid of possible property regimes, starting from rights to access and use, and analyzing their possible entitlements, as well as rights transfer modes, on a scale increasing by number of subjects.

Table 3. Property regimes classification following entitlement and access/use rights transfer modes $\Rightarrow \quad$ increasing number of rights holders $\Rightarrow$

\begin{tabular}{|c|c|c|c|c|}
\hline Property regime & Private property & Common property & Public property & $\begin{array}{c}\text { Absence of } \\
\text { property or free } \\
\text { access }\end{array}$ \\
\hline $\begin{array}{c}\text { Access } \\
\text { entitlement: who } \\
\text { holds rights? }\end{array}$ & $\begin{array}{c}\text { One individual: } \\
\text { physical or juridical } \\
\text { persona }\end{array}$ & $\begin{array}{c}\text { Members of } \\
\text { community or } \\
\text { defined group }\end{array}$ & $\begin{array}{c}\text { Public power: State } \\
\text { or Public } \\
\text { Administration }\end{array}$ & Anyone \\
\hline $\begin{array}{c}\text { Transfer: how are } \\
\text { rights transferred? }\end{array}$ & $\begin{array}{c}\text { Purchase-sale, } \\
\text { donation or } \\
\text { inheritance }\end{array}$ & $\begin{array}{c}\text { Belonging to } \\
\text { community or } \\
\text { group }(*)\end{array}$ & $\begin{array}{c}\text { Administrative act } \\
\text { or regulation }\end{array}$ & Inexistent \\
\hline
\end{tabular}

(*) It can follow different criterias (birth, age, alliance, job, etc.) and entry can be free or upon some form of payment.

Public and private property fit into this analytical framework, but are not the only possible regimes. Beside them we find:

a) absence of property or free access regime, no longer an "anomaly" but as a possible access form to given resources;

b) common property, intermediate regime between private and public property, where the rights holder is neither a private individual subject nor the State, but a defined and identifiable community or group, made up following different criteria.

\section{The tragedy of the commons paradigm}

The main paradigmatic model used in economics about natural resources was formulated in 1968 by Garrett Hardin in a notorious paper, The tragedy of the commons, published by Science.

The central issue Hardin deals with is demography: within a concept-theoretical Malthusian framework, present in those years' discussions which begin to analyze the interface between growth and natural resources, later crystallized in the Limits to Growth report by the Club of Rome, the author discusses technical and moral solutions. His central thesis is the need for demographic control, before the "explosive" growth trends of human population ${ }^{2}$ registered in the first decades after World War II.

The tragedy model is metaphorically illustrated through a "pasture open to all", on which several herdsmen must decide how many animals they put to graze. Each herdsman will rationally decide following his own individual marginal cost-benefit

\footnotetext{
${ }^{2}$ In the cold war's geopolitical climate, J.P. Erlich's The $P$ Bomb graphically compared demographic growth to a nuclear
} mushroom. 
calculations, namely how much it will cost him and how much he will get in return from putting one more animal to graze on the common pasture. Given that the marginal cost (grass grazed) will be borne by the common resource, the single herdsman will only bear a fraction of it, whereas his marginal benefit will be full. The rational comparison between marginal cost and benefit will hence always be such to induce him to place one more animal to graze, regardless of the pasture's total carrying capacity. Each rational herdsman will follow the same logic, whose tragic and unavoidable consequence will be the pasture's exhaustion.

"At this point, the inherent logic of the commons remorselessly generates tragedy. (...) Each man is locked into a system that compels him to increase his herd without limit - in a world that is limited. Ruin is the destination toward which all men rush, each pursuing his own best interest in a society that believes in the freedom of the commons. Freedom in a commons brings ruin to all" [1].

The model's strength is in demonstrating the tragedy's "rationality", as it follows individuals' rational behavior.

How to avoid the tragedy? The author provides two possible solutions to promote a rational (sustainable, in today's language) pasture management: privatization, or State direct management.

What shall we do? (...) We might sell them off as private property. We might keep them as public property, but allocate the right to enter them. (...) But we must choose - or acquiesce in the destruction of the commons [1].

Hardin's model has represented the basis of orthodox economics in analyzing environmental and natural resources' issues. Game theory then placed beside it the model known as "prisoner's dilemma", which analyses individual behavior before a key strategy choice of collective games: betray or cooperate?

Table 4. The prisoner's dilemma

\begin{tabular}{|c|c|c|}
\hline A/B & B cooperates & B betrays \\
\hline A & A: 1 year & A: 3 years \\
cooperates & B: 1 year & B: free \\
\hline A betrays & A: free & A: 2 years \\
& B: 3 years & B: 2 years \\
\hline
\end{tabular}

The dilemma shows that, in a strategic one-shot game and without communication the individual rational strategy is to betray, whereas the collective optimal one would be to cooperate. The dilemma's solution, known as Nash equilibrium, is a double defection strategy, perfectly tuned with Hardin's tragedy, whose conclusions are thus strengthened.

\section{Elinor Ostrom: subverting the mainstream, commons and sustainability}

The deepest and most eminent critics to the mainstream paradigm (tragedy of the commons + prisoner's dilemma) has been developed by Elinor Ostrom, showing the models' inadequacy when applied to the real world, then subverting orthodox economics' conclusions.

The first critics is that Hardin unduly associates commons to free access. In doing that economics is coherent with the modern dichotomy State-market and public-private, but it ignores historical and social realities which, looked upon as pre-modern, are neither private nor public property. In the real world, expecially for important resources, commons are spaces and natural goods which are not "open to all", under open access, but rather collective ones, appropriated and managed by limited groups, according to defined modes and rules; besides, one can observe that, historically, commons are the rule, whereas open access is the exception. These realities cannot just be ignored or held irrelevant, also because, despite the modern historical process of enclosures' expansion, today the commons still represent the living proof of realities where, even in the absence of the State Leviathan or of private property, the tragedy has not historically taken place.

Hardin's model's tragic forecast does apply to open access, once the pressure scale on the resource overshoots its natural renewing threshold. Hence Hardin's tragedy does not concern the commons, but open access: common property represents indeed one of the possible responses to the tragedy, whose forms go beyond the public-private, state-market dichotomy. Hardin's misunderstanding is to consider a cause of the problem what in reality is one possible solution. As empirical studies worldwide clearly show, collective institutions, often centuries-old, effectively manage quite complex environmental systems and natural resources. The model's misunderstanding leads to ignore or destroy them, whereas the true challenge for economic science, through interdisciplinary dialogue, is to deeply study and understand them.

Another critique concerns individual rationality. In Hardin's model and in the Nash equilibrium rational actors ignore environmental information, do not communicate and are unable to cooperate. In real life substantive and calculating rationality is not the only one: actors do perceive environmental and collective effects of their choices, they can communicate and cooperate and, although fallible, they do make up rules and create institutions to face common problems. By using laboratory experimental economics techniques, Ostrom et al. [5] show that the tragedy does take place with no communication, but when players can talk to each other cooperation gains space and results change dramatically, outdoing $90 \%$ of theoretical optimum with neither 
privatization nor centralized resource management. Hence, if commons' users can communicate and set their own rules, commons-based emerging institutions can show to be more efficient than State and market.

Ostrom devoted her work to identify sustainability features in commons based natural resources' management models. To do that she innovated in economics research, especially in field case studies and cross-disciplinary methods. The whole of her work, from her milestone Governing the Commons [5] to most recent papers, is a very rich legacy (she died in 2012), dense in hints and stimuli to shift terms of economic and other scientific sustainability studies, from "managing economic and/or ecological systems" to "governing socio-ecosystems", by considering and respecting their internal diversity and complexity.

Among the developments of the socio-ecosystems' sustainability studies Ostrom lead and inspired is the recognition of the key role of institutional - hence socio-cultural, not only biological - diversity to strengthen resilience, a key resource for sustainability. Just like over the last decades scientific consensus has grown on the relevance of biodiversity for sustainability, the evidence accumulated show that the same stands for institutional diversity, even if scientific consensus on this idea still needs to rise [7].

\section{Indigenous Lands: sustainable commons threatened by economic growth}

Indigenous Lands in Brazil legally feature a common property regime [4]. They protect biodiversity more effectively than other protected areas [2]. They are a living proof - all but negligible, making up 13\% of Brazil - of commons' sustainability.

Today, they are threatened by Brazil's economic boom, and the neo-extractive South American role in the global economy, based on agro-business expansion and infra-structure projects to integrate the Amazon to a global economy ever hungrier for natural resources. New global political alliances are urgently needed to shift the world economy towards sustainability. A key agenda point of a global sustainability alliance would be to counter the commodity consensus on which Latin America's economy is growing [9], as economic pressures on Indigenous commons undermine socio-cultural diversity, hence the resilience of the whole socio-ecosystem Earth.

\section{Bibliography}

1. G. Hardin, "The Tragedy of the Commons", Science, 162 (1968)

2. V.M. Lauriola, "Quem conserva a biodiversidade na Amazônia? Uma análise comparada da eficiência econômico-ecológica de Terras Indígenas e Unidades de Conservação”, Boletim da ECOECO, 14 (2006)

3. V. M. Lauriola, "Elinor Ostrom. Nobel eterodosso e rosa-verde. Un segno di speranza?", I Frutti di Demetra, 22 (2011)

4. V. M. Lauriola, "Indigenous Lands, Commons, Juridical Pluralism and Sustainability in Brazil", Journal of Latin American Geography, 12, 1 (2013)

5. E. Ostrom, Governing the Commons. The evolution of institutions for collective action (1990)

6. E. Ostrom, R. Gardner, J. Walker, Rules, games and common-pool resources (1994)

7. E. Ostrom, Diverse Governance Arrangements for Ecological Sustainability, ESEE Conference (2007)

8. D. Ricardo, On the principles of political economy and taxation (1821)

9. M. Svampa, «Consenso de los Commodities» y lenguajes de valoración en América Latina, Nueva Sociedad, 244 (2013) 